\title{
Technical and Economic Analysis of LCT (Landing Craft Tank) Vessel Conversion into Non- Conventional LNG (Liquid Natural Gas) Carriers
}

\author{
Hayy Nur Abdillaha,", Ketut Buda Artana ${ }^{\mathrm{b}}$, I Made Arianac and Achmad Agoes Masroerid \\ Department of Marine Engineering, Sepuluh Nopember Institute of Technology, Surabaya, \\ Indonesia \\ a.hayyabdillah.17042@mhs.its.ac.id,b.ketutbuda@its.ac.id, c.ariana@its.ac.id,d. \\ masroeri@its.ac.id \\ *corresponding author
}

Keywords: $\quad$ LCT, LNG, stability, economic analysis

Abstract: Indonesia was among those countries which decided to increase its natural gas consumption, due to its relative low cost and lack of impact on the environment. LNG can be used as an alternatives energy to modify high carbon energy consumption. Indonesia has several gas power plant, one of them is Siantan power plant in Pontianak but the location near the watershed. This location makes it difficult for ships with low draft to supply LNG, even though ship is the right choice to distribute LNG in large quantities. This study is aimed to develop the logistic in the Indonesia watershed zone base on technical and economical analysis of LCT vessel conversion into non-conventional LNG carrier. Output of this research are general arrangement of LCT vessel carrying non-conventional LNG, detail drawing of the seating on main deck, lashing system on main deck and between ISO LNG tank. Economic analysis after the LCT conversion required Capital Expenditure (CAPEX) and Operational Expenditure (OPEX). CAPEX consist cost of purchasing vessels, conversion fees, administration and other start-up capital, while OPEX is the cost required for ship operations. From the calculations, the LNG provider will be able to invest in margins from \$ 1.55 for scenario ship- 1 and provider will be able to invest in margins from $\$ 1.15$ for scenario ship-2.

\section{Introduction}

The world primary energy will increase in line with population growth and world economic development. Increased energy demand make energy sources increasing. According to the International Energy Agency (IEA) 80\% of the world's energy supplied from fossil fuels [4], while fossil fuel sources are limited amount and belong to the non-reversible energy [5]. The solution that can be made to these limitations is look for the other renewable energy alternatives and good on environmentally. LNG (Liquid Natural Gas) can be used as an alternative energy, some advantages using LNG which are natural gas on earth is greater than the fossil fuel reserves and LNG prices 
cheaper than non-subsidized diesel oil. The high dependence on oil makes natural gas as an alternative choice, increasing the gas demand accompanied by transportation in large load [6]. The right solution to cover that issues is provide gas supplies transportation with large quantities. Some power plant in Indonesia has distribution problem like as Bintuni power plant in West Papua; Barito power plant in South Kalimantan; and Siantan power plant in Pontianak where their location near the watershed, so ship with high draft cannot supply to this area. As shown in figure 1. Location of Siantan power plant in Pontianak near the watershed.

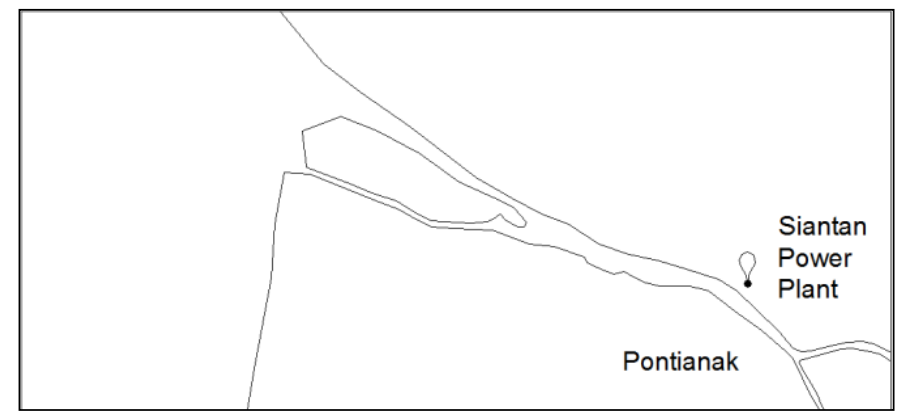

Figure 1. Location of Siantan power plant in Pontianak

Sources: Seaport.com

Transportations have limitation to supply Indonesian watershed area or coastal areas so that innovation needed to develop ship which can carried large load as transportation. Based on that description conversion of LCT vessel into non-conventional LNG carriers can be used as an alternative solution so that supply of gas energy in the Indonesian watershed can be fulfilled. In this research the LCT route will be operated as shown in figure 2 from Batam to Siantan power plant in Pontianak that has capacity $30 \mathrm{MW}$. Output of this research are general arrangement of the LCT vessel non-conventional LNG carriers, ship stability after conversion, and economic analysis after this vessel converted into the non-conventional LNG carriers.

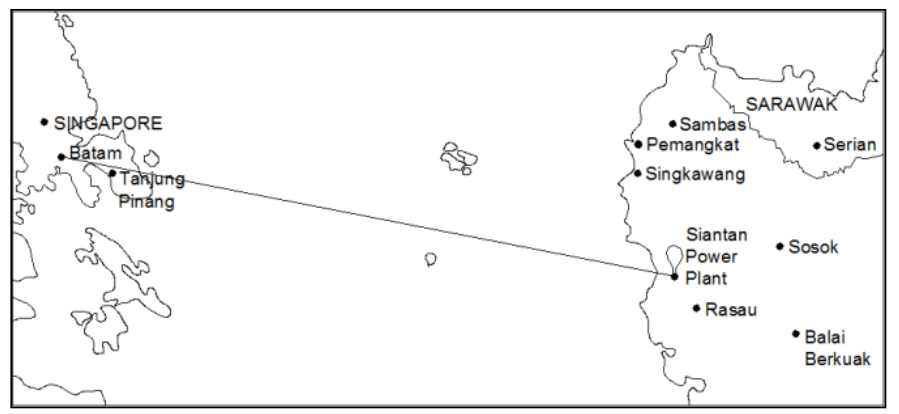

Figure 2. Route from Batam to Siantan power plant in Pontianak

Sources: Seaport.com

\section{Literature Review}

\subsection{LCT}

The LCT (Landing Craft Tank) is a type of vessel designed for military purposes. But now LCT ships used to transport passengers, cargo, heavy equipment and construction materials that can be transported to watershed that are difficult to reach by high draft ships. LCT in Indonesia is used for commercial purposes operating in watershed area, the advantages of the LCT vessel is not require a 
special port in loading process because it has a ramp door, which can be used like as a ferry to carrying passengers, heavy equipment, cargo, materials construction and transport equipment, the LCT vessel has a low draft so it is possible to operate in watershed area.

\subsection{LNG}

Liquefied Natural Gas (LNG) is one of natural gas (Methane-CH4) products, where natural gas is cooled by cooling to $160 \mathrm{oC}$ at a pressure of 1 atmosphere which makes it liquid and the volume becomes 1/600. This liquid condition can be carried out in large quantities. LNG have to desulfurization, dehydration, and carbon dioxide cleaners before carried out. All of these processes make the gas colourless, transparent, odourless, non-toxic and avoid the sulphur oxide and ash. Some of the benefits of using LNG as a fuel are good on environmentally because of lower carbon content and can reduce sulphur oxide ( $\mathrm{SO}$ ) [3]. LNG is a clean energy (1 KWH of 446 grams of gas energy) as well as less nitrogen oxide (20-37\%) and carbon dioxide (57\%) than coal. If LNG contact with the air will produce a white vapour that is easily visible. Because the LNG vapour is lighter than the air, it evaporates upwards. In addition because of the spontaneous flame temperature of LNG is higher than gasoline, this nature makes LNG a relatively safer energy. Since LNG has high calories (12000 $\mathrm{kcal} / \mathrm{kg}$ ) compared to other fossil fuels such as coal and petroleum [2].

\subsection{Stability Analysis}

Stability is the ability of an object to return to its original state / position. So the stability of the vessel is the ability of the vessel to back to stable condition when it unstable because of the waves and other loads. In a ship design process, vessel stability is an absolute calculation to determine whether the design of the vessel made is stable. There are two stability calculations for ships, intact stability and demage stability. Intact stability is the calculation of stability when the ship is intact or under no leakage in any compartment calculated on some tank condition for each degree. The intact stability calculation is performed to determine the ability of the vessel to return to its equilibrium position. Calculation of damage stability is the calculation of the leaked vessel or when the ship is experiencing damage or leakage calculated on some condition for each degree. This damage stability calculation is performed to determine how much the ship's ability to withstand the leak so the vessel remains stable when the ship's hull is damaged or leaked due to accident or unwanted conditions.

The Stability Criteria required by IMO regulation A. 749 (18) states that at the angle of 0o to 30 o the area under the curve of the GZ stand shall not be less than $0.055 \mathrm{~m} . \mathrm{rad}$, at angles $0 \mathrm{o}$ to $40 \mathrm{o}$ area under the curve of the GZ stand shall not be less than $0.09 \mathrm{~m} . \mathrm{rad}$, at the angle of 30o to 40o area under the curve of the GZ stand shall not be less than $0.03 \mathrm{~m} . \mathrm{rad}$, at the angle of inclination 30o or more of the GZ stand shall not be less than $0.2 \mathrm{~m}$, the angle at the maximum of GZ shall not be less of $25 \mathrm{o}$, the initial metacentre value or initial GMt should not be less than $0.15 \mathrm{~m}$.

\subsection{Lashing System}

Lashing system is a system that regulates how the lashing arrangement of the ship, either a lashing on the deck to the cargo or lashing between the cargo itself. Common terms used in lashing system are bays, rows and tiers. Bays in the layout system is a sign of longitudinal number starting from the front with an odd number record for container 20 feet and even number is used for container 40 feet. Rows in the layout system are a sign of trans verse numbers starting from the middle and seen from the back. While the tiers in the layout system are vertical markings. Based on BKI Volume I (Rules for stowage and lashing of containers) for 1 tier the minimum length of rope is $354 \mathrm{~cm}$ at the angle $43^{\circ}$, at 2 tier the minimum length of rope at least $560 \mathrm{~cm}$ at the angle of $24^{\circ}$, at 3 tier the length of the rope at least $710 \mathrm{~cm}$ at the angle $18^{\circ}$, while for the 4 tier the minimum length of the rope is 725 $\mathrm{cm}$ at the angle of $18^{\circ}$. 


\section{Result}

\subsubsection{Calculation of Gas Requirement at Siantan Power Plant}

Based on the capacity of $50 \mathrm{MW}$, it needs a gas 6 MMCFD with total demand 43,800 tons per year, so for daily requirement of 120 tons with gas volume $240 \mathrm{~m} 3$ / day this amount equivalent to 6240 MMBTU. Ship route from Batam to Pontianak is $352 \mathrm{Nm}$ and take 50 hours per trip. Time required for loading or unloading is 8 hours, where loading unloading is planned by mobile crane because the ship does not have crane facilities. Based on the description, 116 hours required or equivalent to 5 days for one round trip.

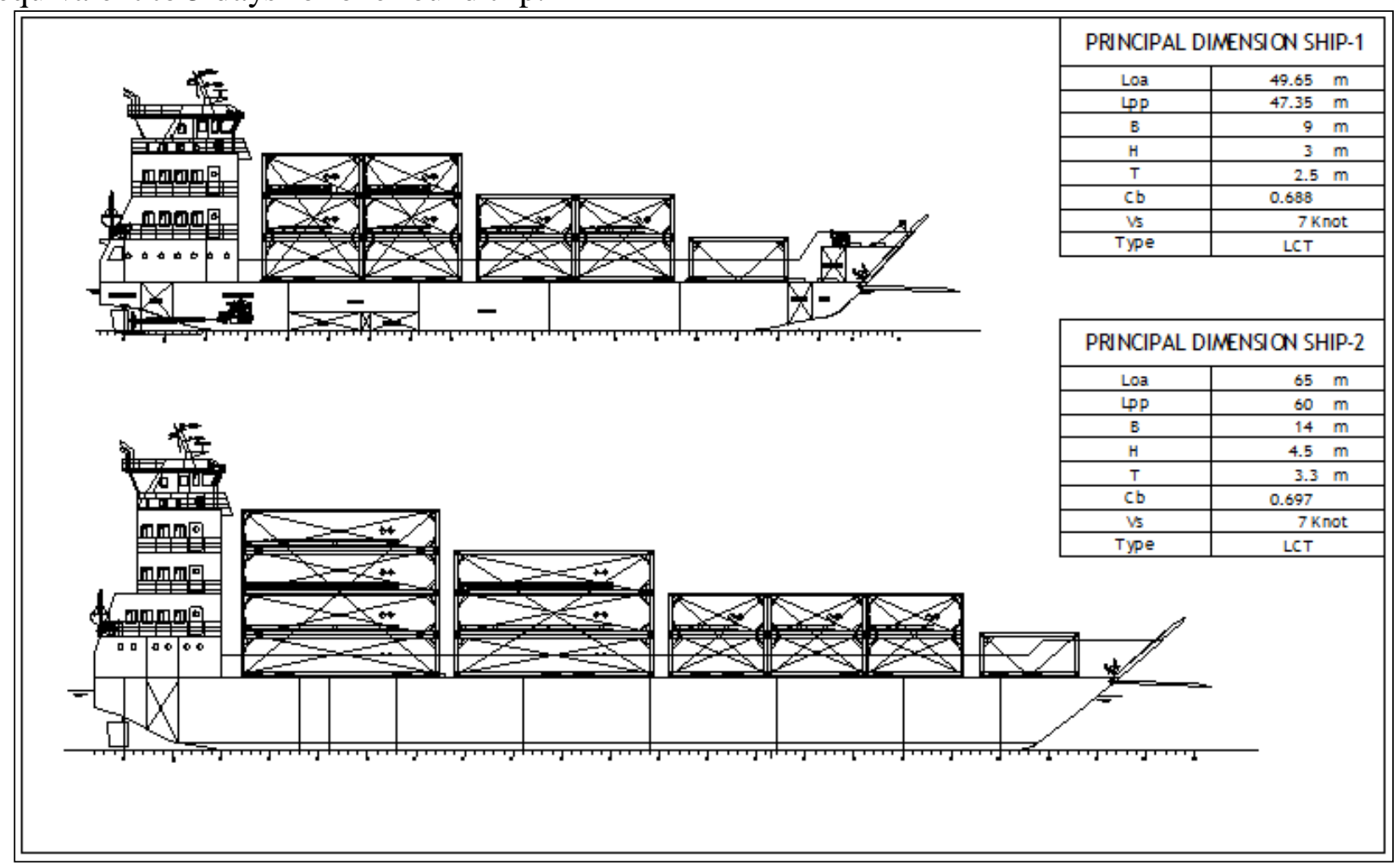

Figure 3. Ship-1 and ship-2 conversion that has been converted into the non-conventional LNG carriers

Figure 3 shows ship- 1 and ship- 2 conversion has been converted into the non-conventional LNG carriers. Ship-1 carrying 34 LNG ISO tank of 20 feet with a total load of 748 ton and ship- 2 carrying 35 LNG ISO tank for size 20 feet and 40 feet with total load 1475 ton. Composition of total LNG ISO tank is shown in Table 1.

Table 1. Total composition of LNG ship-1 and ship-2

\begin{tabular}{|l|c|c|}
\hline \multirow{2}{*}{ Weight calculation (ton) } & \multicolumn{2}{|c|}{ Type of ship } \\
\cline { 2 - 3 } & Ship-1 & Ship-2 \\
\hline Displasement & 751.3 & 1970 \\
\hline LWT & 361.5 & 778 \\
\hline DWT & 500 & 1500 \\
\hline Payload & 482.5 & 1475 \\
\hline Total LNG ISO Tank 20 feet & 32 & 35 \\
\hline Total LNG ISO Tank 40 feet & - & 35 \\
\hline
\end{tabular}




\subsubsection{Stability LCT Non-Conventional LNG Carriers}

Based on demand the first scenario using two LCT vessel (ship-1) has principal dimension Loa: 163 feet, Lpp: 155 feet, B: 9 feet, H: 9.8 feet, T: 8.2 feet, Vs: 7 knots. Second scenario using just one LCT vessel (ship-2) has principle dimension Loa: 213 feet, Lpp: 197 feet, B: 46 feet, H: 15 feet, T: 11 feet, Vs: 7 knots. The different load and addition of the construction make stability changed, to determine the condition after conversion ship modelling is created in Maxsurf software in each scenario of the ship- 1 shown in figure 5 and ship- 2 shown in figure 6 . The result of stability analysis with two conditions, full load conditions and empty load conditions based on IMO regulation shown in Table 2.

Table 2. Result of stability analysis

\begin{tabular}{|l|c|c|c|c|}
\hline \multirow{2}{*}{ Stability Criteria } & \multicolumn{2}{|c|}{ Before conversion } & \multicolumn{2}{c|}{ After conversion } \\
\cline { 2 - 5 } & Ship-1 & Ship -2 & Ship -1 & Ship -2 \\
\hline $\begin{array}{l}\text { Area } 0^{\circ} \text { to } 30^{\circ} \text { from the greather of } \\
\text { spec. heel angle }\end{array}$ & $0.379 \mathrm{~m} . \mathrm{rad}$ & $0.945 \mathrm{~m} \cdot \mathrm{rad}$ & $0.157 \mathrm{~m} . \mathrm{rad}$ & $0.836 \mathrm{~m} . \mathrm{rad}$ \\
\cline { 2 - 5 } $\begin{array}{l}\text { Area } 0^{\circ} \text { to } 40^{\circ} \text { from the greather of } \\
\text { spec. heel angle }\end{array}$ & Accepted & Accepted & Accepted & Accepted \\
\cline { 2 - 5 } $\begin{array}{l}\text { Area } 30^{\circ} \text { to } 40^{\circ} \text { from the greather } \\
\text { of spec. heel angle }\end{array}$ & Accepted & Accepted & Accepted & Accepted \\
\cline { 2 - 5 } & Accepted & Accepted & Accepted & Accepted \\
\hline \multirow{2}{*}{ Maximum $\mathrm{GZ}$ at $30^{\circ}$ or greather } & $0.936 \mathrm{~m}$ & $2.92 \mathrm{~m}$ & $0.782 \mathrm{~m}$ & $2.238 \mathrm{~m}$ \\
\cline { 2 - 5 } & Accepted & Accepted & Accepted & Accepted \\
\hline \multirow{2}{*}{ Angle of maximum GZ } & $26^{\circ}$ & $29.7^{\circ}$ & $34.2^{\circ}$ & $30.4^{\circ}$ \\
\hline \multirow{2}{*}{ Initial $\mathrm{GM}_{\mathrm{t}}$} & Accepted & Accepted & Accepted & Accepted \\
\cline { 2 - 5 } & $3.354 \mathrm{~m}$ & $7.901 \mathrm{~m}$ & $2.173 \mathrm{~m}$ & $6.905 \mathrm{~m}$ \\
\cline { 2 - 5 } & Accepted & Accepted & Accepted & Accepted \\
\hline
\end{tabular}

\subsubsection{Detail Drawing Seating System}

Non-conventional LNG need seating system to be able to tied and placed on the main deck. As shown in figure 4 shows the detail construction of seating system non-conventional LNG ISO tank ship-1 and ship 2. This detail showing the seating construction of the deck with the I bottom profile connected to the $\mathrm{T}$ profile below the deck, so that there is transverse force of the vessel to be forwarded to the bottom construction on the right and left side of the hull. Profile I welded on the deck section above the T profile on the main deck of the LCT main deck so that the support from this non-conventional LNG on the deck construction.

\subsubsection{Economical Analysis}

In this research used two variables to determination investment, Capitan Expenditure (CAPEX) and Operational Expenditure (OPEX). Capital expenditure (CAPEX) represents all initial investment costs, the allocation of planned funds (in budget) to make purchases / repairs / replacements of everything that is categorized as an accounting company's assets. In this study the value of investment required for the 1 -ship scenario is $\$ 3,330,000$ while for the 2 -ship scenario is $\$$ $3,980,000$.

Operational expenditure (OPEX) is all costs need to perform operations for a certain period. In the calculation of this case period is determined for 5 years. On the side of the ship provider the required operational costs include salary of crew ship, vessel maintenance cost, main engine fuel costs and auxiliary machines, port administration costs, port charge, and salary of mobile crane 
operators. In the process of LNG supply requires the operational cost for ship-1 (total 2 ship) is for $\$ 2,217,219$, while for ship-2 (total 1 ship) is $\$ 1,224,091$.

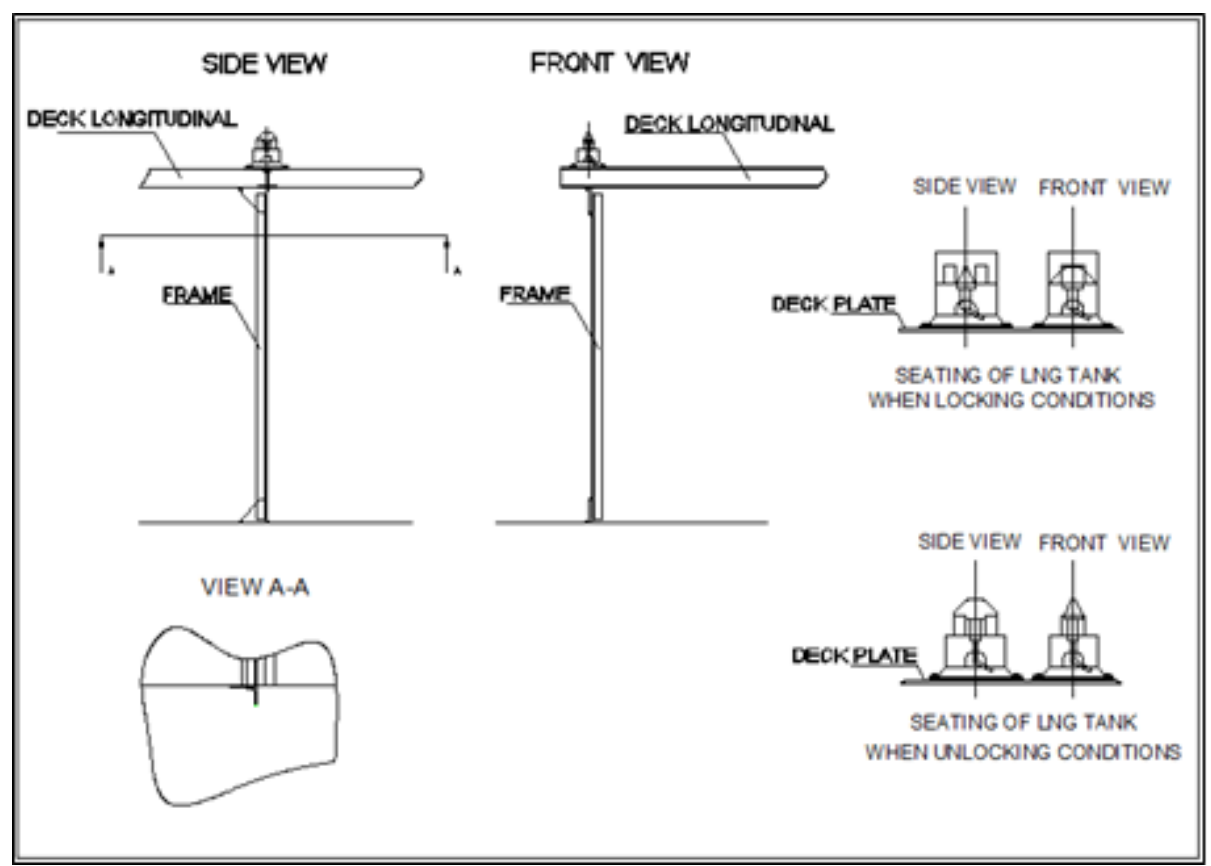

Figure 4. Detail drawing LNG seating system

Table 3 and Table 4 show the annual income of the varied margin, the LNG price is assumed $\$ 7$ over the 5 year contract period. The margin of LNG price on ship-1 start from $\$ 1.5, \$ 1.55, \$ 1.6$, $\$ 1.65$ and $\$ 1.7$ so each mmbtu has a selling value of $\$ 8.5, \$ 8.55, \$ 8.6, \$ 8.65$ and $\$ 8.7$. Table 5 shown the economic calculation of the ship-1 scenario which describes the purchase and selling value of LNG with the revenue, NPV, IRR and payback period of the project, while table 6 presents the results economic calculation of the ship-2 scenario with margin start from $\$ 1.1, \$ 1.15, \$ 1.2, \$ 1.25$ and $\$ 1.3$ so each mmbtu has a selling value $\$ 8.1, \$ 8.15, \$ 8.2, \$ 8.25$ and $\$ 8.3$.

Table 3. Revenue ship-1

\begin{tabular}{|c|c|c|c|}
\hline Margin & Purchase price / mmbtu (\$) & Selling price/ mmbtu (\$) & Revenue $(\$)$ \\
\hline$\$ 1.50$ & 7 & 8.50 & $3,146,400$ \\
\hline$\$ 1.55$ & 7 & 8.55 & $3,530,280$ \\
\hline$\$ 1.60$ & 7 & 8.60 & $3,644,160$ \\
\hline$\$ 1.65$ & 7 & 8.65 & $3,758,040$ \\
\hline$\$ 1.70$ & 7 & 8.70 & $3,871,920$ \\
\hline
\end{tabular}

Table 4. Revenue ship-2

\begin{tabular}{|c|c|c|c|}
\hline Margin & Purchase price / mmbtu (\$) & Selling price/ mmbtu (\$) & Revenue $(\$)$ \\
\hline$\$ 1.10$ & 7 & 8.10 & $2,505,360$ \\
\hline$\$ 1.15$ & 7 & 8.15 & $2,619,240$ \\
\hline$\$ 1.20$ & 7 & 8.20 & $2,733,120$ \\
\hline$\$ 1.25$ & 7 & 8.25 & $2,847,000$ \\
\hline$\$ 1.30$ & 7 & 8.30 & $2,960,880$ \\
\hline
\end{tabular}


Table 5. Economic analysis ship-1

\begin{tabular}{|c|c|c|c|c|}
\hline Year & Margin & NPV & PP & IRR (\%) \\
\hline 1 & $\$ 1.50$ & 436,923 & 2.01 & $12 \%$ \\
\hline 2 & $\$ 1.55$ & 783,494 & 1.93 & $16 \%$ \\
\hline 3 & $\$ 1.60$ & $1,130,065$ & 1.86 & $20 \%$ \\
\hline 4 & $\$ 1.65$ & $1,476,636$ & 1.80 & $23 \%$ \\
\hline 5 & $\$ 1.70$ & $1,823,208$ & 1.75 & $27 \%$ \\
\hline
\end{tabular}

Table 6. Economic analysis ship-2

\begin{tabular}{|c|c|c|c|c|}
\hline Year & Margin & NPV & PP & IRR (\%) \\
\hline 1 & $\$ 1.10$ & 550,626 & 2.04 & $12 \%$ \\
\hline 2 & $\$ 1.15$ & 852,402 & 1.97 & $15 \%$ \\
\hline 3 & $\$ 1.20$ & $1,198,973$ & 1.91 & $18 \%$ \\
\hline 4 & $\$ 1.25$ & $1,545,544$ & 1.86 & $21 \%$ \\
\hline 5 & $\$ 1.30$ & $1,892,116$ & 1.81 & $24 \%$ \\
\hline
\end{tabular}

Table 7 and 8 shown the sensitivity analysis on ship- 1 and ship-2, this analysis calculate when CAPEX and OPEX increase 5\%, 10\% and $15 \%$.

Table 7. Sensitivity analysis ship-1

\begin{tabular}{|c|c|c|c|}
\hline \multicolumn{5}{|c|}{ Margin \$1.55 } & IRR \\
\hline Addition of CAPEX and OPEX & NPV & PP & $13 \%$ \\
\hline $5 \%$ & $\$ 464.997$ & 2.1 & $9 \%$ \\
\hline $10 \%$ & $\$ 146.499$ & 2.2 & $5 \%$ \\
\hline $15 \%$ & $\$(171.999)$ & 2.4 & IRR \\
\hline \multicolumn{5}{|c|}{ Margin \$1.6 } & PP & $16 \%$ \\
\hline Addition of CAPEX and OPEX & NPV & 2.0 & $13 \%$ \\
\hline $5 \%$ & $\$ \quad 811.568$ & 2.1 & $5 \%$ \\
\hline $10 \%$ & $\$ 493.070$ & 2.2 & \\
\hline
\end{tabular}

Table 8. Sensitivity analysis ship-2

\begin{tabular}{|c|c|c|c|}
\hline \multicolumn{5}{|c|}{ Margin \$1.55 } \\
\hline Addition of CAPEX and OPEX & NPV & PP & IRR \\
\hline $5 \%$ & $\$ \quad 680.517$ & 2.1 & $14 \%$ \\
\hline $10 \%$ & $\$ \quad 508.326$ & 2.1 & $12 \%$ \\
\hline $15 \%$ & $\$ \quad 335.784$ & 2.2 & $11 \%$ \\
\hline \multicolumn{5}{|c|}{ Margin \$1.6 } & PP & IRR \\
\hline Addition of CAPEX and OPEX & NPV & 2.0 & $17 \%$ \\
\hline $5 \%$ & $\$ 1.027 .088$ & 2.1 & $15 \%$ \\
\hline $10 \%$ & $\$ 854.897$ & 2.2 & $14 \%$ \\
\hline $15 \%$ & $\$ 682.355$ & & \\
\hline
\end{tabular}




\section{Conclusion}

Optimal size of the vessel between the two scenarios performed by the authors based on previous research to supply LNG at Siantan power plant in Pontianak with capacity of $30 \mathrm{MW}$ has Loa 213 feet, Loa : 163 feet, Lpp: 155 feet, B: 9 feet, H: 9.8 feet, T: 8.2 feet, Vs: 7 knots. Stability analysis after conversion based on IMO regulation A 749 (18) are the area under the GZ $0^{\circ}$ to $30^{\circ}$ : $0.836 \mathrm{~m} . \mathrm{rad}$, the area under the GZ $0^{\circ}$ to $40^{\circ}: 1.014 \mathrm{~m} \cdot \mathrm{rad}$, the area under the GZ 30o to 40o : 0.318 m.rad, GZ arm at 30o : 2,238 m, angle at maximum of GZ : 30.4o, and initial GMt : 6,905 m. Conversion of LCT vessel into LNG carrier including seating system and lashing system, while the lashing system based on BKI Volume I part 4 which regulates the lashing system on the container tank.

The economic analysis of the ship-1 scenario, investor can start his business starting from margin $\$ 1.55$ while the ship-2 scenario investor can start his business starting from margin $\$ 1.15$ so that the ship-2 scenario is more profitable with the NPV (Net Present Value) : \$852,402, IRR (Interest Rate of Return) : 15\%, and PP (Payback Period) : 1.97 years.

\section{References}

1. Agastana, I. B. 2016. Conceptual Design of LNG Bunkering Shuttle inSurabaya West Access Channel (SWAC). Surabaya: Institut Teknologi Sepuluh Nopember.

2. Artana, Ketut Buda dan Soegiono. 2006. Transportasi LNG Indonesia. Surabaya: Airlangga University Press.

3. Hedzrik, J., 2011. LNG as a Marine Fuel-Possibilities and Problems. KONES Powertrain and Transport. Volume 18.

4. International Energy Agency (IEA). 2015. Southeast Asia Energy Outlook. World Energy Outlook Special Report.

5. International Energy Agency (IEA). 2015. World Energy Outlook 2015. ICC. Istituto Internazionale Delle Comunicatizioni. Technical assessment on LNG based on cryogenic Nonkonvensional containers.

6. Prabaswara, R. dan W. D. Aryawan. 2013. Perancangan Kapal LCT (Landing Craft Tank) Pengangkut CNG (Compressed Natural Gas) Berbahan Bakar Gas di Daerah Kalimantan Timur. Jurnal Teknik POMITS 2(1): 1

7. Saputro, G. 2015. Kajian Teknis dan Ekonomis Sistem Bunkering LNG untuk bahan bakar gas di Kapal. Surabaya: Institut Teknologi Sepuluh Nopember.2. 